\title{
Discernible rhythm in the spatio/temporal distributions of transatlantic dust
}

\author{
Y. Ben-Ami ${ }^{1}$, I. Koren ${ }^{1}$, O. Altaratz ${ }^{1}$, A. Kostinski ${ }^{2}$, and Y. Lehahn ${ }^{1,3}$ \\ ${ }^{1}$ Department of Environmental Sciences and Energy Research, Weizmann Institute of Science, Rehovot, Israel \\ ${ }^{2}$ Department of Physics, Michigan Technological University, Houghton, Michigan, USA \\ ${ }^{3}$ Department of Geophysics and Planetary Sciences, Tel Aviv University, Tel Aviv, Israel
}

Correspondence to: I. Koren (ilan.koren@weizmann.ac.il)

Received: 27 July 2011 - Published in Atmos. Chem. Phys. Discuss.: 19 August 2011

Revised: 5 January 2012 - Accepted: 9 January 2012 - Published: 1 March 2012

\begin{abstract}
The differences in North African dust emission regions and transport routes, between the boreal winter and summer, are thoroughly documented. Here we re-examine the spatial and temporal characteristics of dust transport over the tropical and subtropical North Atlantic Ocean, using $10 \mathrm{yr}$ of satellite data, in order to better characterize the different dust transport periods. We see a robust annual triplet: a discernible rhythm of "transatlantic dust weather".

The proposed annual partition is composed of two heavy loading periods, associated here with a northern-route period and southern-route period, and one light-loading period, accompanied by unusually low average optical depth of dust. The two dusty periods are quite different in character: their duration, transport routes, characteristic aerosol loading and frequency of pronounced dust episodes.

The southern-route period lasts $\sim 4$ months. It is characterized by a relatively steady southern positioning, low frequency of dust events, low background values and high variance in dust loading. The northern-route period lasts $\sim 6.5$ months and is associated with a steady drift northward of $\sim 0.1$ latitude day ${ }^{-1}$, reaching $\sim 1500 \mathrm{~km}$ north of the southern-route. The northern period is characterized by higher frequency of dust events, higher (and variable) background and smaller variance in dust loading. It is less episodic than the southern period.

Transitions between the periods are brief. Separation between the southern and northern periods is marked by northward latitudinal shift in dust transport and by moderate reduction in the overall dust loading. The second transition, between the northern and southern periods, commences with an abrupt reduction in dust loading and rapid shift southward of $\sim 0.2$ latitude day ${ }^{-1}$, and $\sim 1300 \mathrm{~km}$ in total.
\end{abstract}

Based on cross-correlation analyses, we attribute the observed rhythm to the contrast between the northwestern and southern Saharan dust source spatial distributions. Despite the vast difference in areas, the Bodélé Depression, located in Chad, appears to modulate transatlantic dust patterns about half the time.

\section{Introduction}

It is well recognized that mineral dust is an essential component in a range of processes involving Earth's radiative budget (e.g. Haywood et al., 2003), generation of clouds and rain (e.g. Prenni et al., 2009), atmospheric chemistry (Usher et al., 2003), biogeochemical cycles (e.g. Jickells et al., 2005), and it has an important impact on human lives (e.g. Ozer et al., 2007). The Atlantic Ocean is the major pathway of dust transport from North Africa, the latter being the Earth's largest source of mineral dust (e.g. Huneeus et al., 2011). Therefore, transatlantic dust is of special importance.

North African dust sources are spread over six major regions: (a) over dry lakes in Tunisia and Northern Algeria, (b) along the foothill of the Atlas Mountains and the western coast and Mauritania (c) along the border between Mali and Algeria, (d) in Central Libya and (e) over southern Egypt and Northern Sudan. Regions b and c occupy vast regions over northwest Africa. Additional source area is (f) the Bodélé depression, recognized as the most intense dust source in North Africa (Koren et al., 2006; Huang et al., 2010; Formenti et al., 2011) located in the south-central part of the Sahara.

Dust transport over the Atlantic has been extensively studied using a variety of sensors, models, and data-sets such as 
satellite retrievals (e.g. Karyampudi et al., 1999; Chiapello and Moulin, 2002; Torres et al., 2002; Kaufman et al., 2005a; Huang et al., 2010; Christopher and Jones, 2010), field experiments (e.g. Reid et al., 2003; Ansmann et al., 2011), long records of ground measurements in the western Atlantic (Prospero, 1996, 1999), back-trajectory analysis (e.g. Engelstaedter et al., 2009) and transport models (e.g. Ginoux et al., 2004; Schepanski et al., 2009). These studies recognized a pronounced annual cycle, marked by a latitudinal shift in the transport route over land and ocean and by change in the location of the active dust sources.

Semi-annual "beat" of the Inter Tropical Convergence Zone (ITCZ) that modulates shifts in the prevailing meteorological conditions, the resulting triggering of some of the North African dust sources, and the actual advection of dust, form a complex chain towards transatlantic dust transport. Are there any robust patterns to be expected? To put our questions in proper context, we shall briefly review relevant spatio/temporal patterns discussed in prior literature.

During the boreal summer the border between the northeasterly, dry and hot Harmattan trade winds, the West African heat low, and the monsoon southwesterly flow of moist and cool air from the tropical Atlantic creates the Inter Tropical Front (ITF) (Janicot et al., 2008; Lavaysse et al., 2009; Lélé and Lamb, 2010). The ITF is located a few hundred kilometers ahead of the ITCZ. It supports favorable conditions for dust emission, mainly over the northwestern part of Africa, such as enhanced surface gustiness (Engelstaedter and Washington, 2007). Towards the boreal winter, the synoptic systems retreat to the south, and the Harmattan winds become an important mechanism for emission of dust. A low level jet, frequently embedded within the Harmattan winds, triggers emission of dust over the Bodélé depression in Chad (Washington and Todd, 2005), a vigorous dust source on a global scale.

Throughout the year, the dust is transported through an east-west corridor over the tropical and subtropical Northern Atlantic. The corridor is generally bounded by the ITCZ in the south, and westerly winds at mid-low level (located north of $\sim 25-30^{\circ} \mathrm{N}$ ) in the north (Christopher and Jones, 2010). The transport route over the ocean moves along the meridian, in accordance with the shift of the synoptic systems over land. The spatial distribution of the Aerosol Optical Depth (AOD) of dust $\left(\tau_{\mathrm{d}}\right)$ along the seasons is shown in Fig. 1a-d.

During the boreal summer, the dust is transported westward, towards the Caribbean Sea and the southern part of North America (Huang et al., 2010). Generally it is embedded within the Saharan Air Layer (SAL), centered at $700 \mathrm{hPa}$, above the northeasterly cooler and moister trade winds of the marine boundary layer (Prospero and Carlson, 1972; Prospero and Nees, 1977; Karyampudi and Carleson, 1988; Karyampudi et al., 1999). Part of the dust is transported within the marine boundary layer (Reid et al., 2002; Ben-Ami et al., 2009). Occasionally, the dust is transported via a northern route, by the anticyclonic flow, ove the Azores
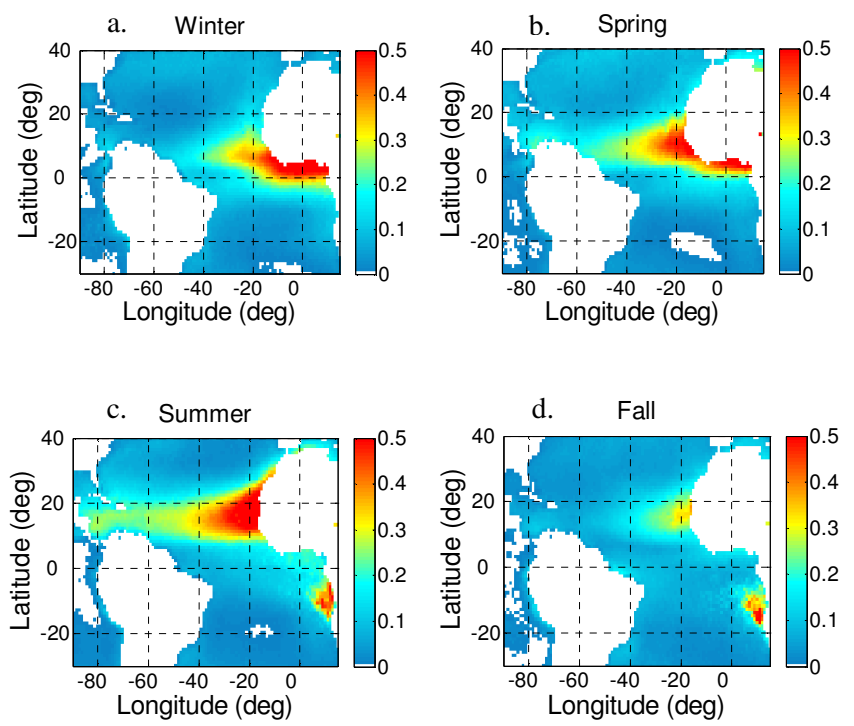

Fig. 1. Seasonal averaged values of daily $\tau_{\mathrm{d}}$ for (a) the boreal winter (December-February), (b) spring (March-May), (c) summer (JuneAugust) and (d) fall (September-November), for the years 20002009.

or Canaries Islands (Karyampudi et al., 1999). In situ measurements show that the SAL has frontal characteristics, including gradients in dust concentration, temperature, relative humidity, and winds that are pronounced along its leading and southern edges (Karyampudi et al., 1999; Reid et al., 2003).

During the boreal winter the dust transport routes shift southward, in accordance with the shift of the synoptic systems and the derived location of the active dust sources. Northwestern African dust sources become less active and the Bodélé become the most persistent active dust source (Engelstaedter and Washington, 2007). The dust, partly mixed with biomass burning smoke (Formenti et al., 2008), crosses the coast of West Africa over the Gulf of Guinea, centered at $\sim 4^{\circ} \mathrm{N}$, and is advected towards the northern part of South America. Results from recent field experiments show that the characteristic vertical structure of the aerosol column, over West Africa and the Eastern Atlantic, is dust in lower altitudes, up to $\sim 2 \mathrm{~km}$, and a mixed dust and biomass smoke layer at the upper few kilometers (Formenti et al., 2008; Johnson et al., 2008a; Ansmann et al., 2011; Knippertz et al., 2011; Weinzierl et al., 2011). They also show the dominance of dust in those winter plumes: mineral dust contributes $72 \%$ of the aerosol mass in aged elevated biomass burning layers, $91 \%$ in fresh biomass burning layers and up to $93 \%$ in plumes of mineral dust (Formenti et al., 2008).

Detailed description of dust transport during the boreal summer months is given in Karyampudi et al. (1999), Reid et al. (2003), Schepanski et al. (2009) and Huang et al. (2010) and during the boreal winter in Kalu (1979), Schepanski et al. (2009) and Huang et al. (2010). 
Overall, previous studies approached the North African dust transport over the Atlantic Ocean within the traditional temporal partition of the year, generally the quarterly monthly partition (DJF MAM JJA SON) as markers for changes in dust transport patterns. The tacit assumption is that temporal variations in dust loading follow the conventional seasonal division. Here we ask whether the conventional seasonal divisions constitute the best framework to study and describe the transatlantic dust routes.

In order to answer this question, we investigate the spatial and temporal transport patterns of dust loading over the Atlantic Ocean to extract the natural annual cycle of dust over this region and to find improved markers for dust transport periodicity. We then proceed to compare dust emission pattern from the Bodélé depression to the transport patterns in order to interpret the observed differences between the dust periods.

\section{Data}

The annual cycle of North African dust over the Atlantic Ocean was studied using daily retrievals of total AOD $(\tau)$ at $550 \mathrm{~nm}$, obtained from the MODerate resolution Imaging Spectroradiometer (MODIS) instrument aboard Aqua and Terra satellites. We used Aqua data for the dates between June 2002 and December 2009 and Terra data for April 2000 until December 2009, both in spatial resolution of $1^{\circ}$. All data were taken from collection 5, except the data for 2009, Aqua, when only collection 51 was available. Over ocean the expected error for MODIS retrievals is $\pm 0.03+0.05 \tau$ (Remer et al., 2008).

The AOD is a result of extinction by all aerosol types suspended in the atmospheric column. Over the Atlantic Ocean, $\tau$ is likely to be the sum of mineral dust, maritime and anthropogenic aerosol from urban and industrial sources and from biomass burning. The fraction of $\tau$ associated with desert dust, $\tau_{\mathrm{d}}$, is estimated in this work using the following parameters: (a) MODIS retrieval of aerosol fine mode fraction, defined as the fractional contribution of aerosol with diameter $<1 \mu \mathrm{m}$ to the total $\tau$ and attributed to all types of aerosol, (b) estimation of the aerosol fine mode fraction for each one of the three types of aerosol, and (c) estimation of marine AOD, based on the wind speed at $1000 \mathrm{hPa}$, acquired from the National Center for Environmental Prediction (NCEP) reanalysis (Kalnay et al., 1996). Detailed descriptions of the method can be found in Kaufman et al. (2005a) and Yu et al. (2009).

Note that this algorithm for extracting $\tau_{\mathrm{d}}$ is based on some assumptions regarding the prevalent conditions of dust, maritime and anthropogenic aerosol loading that were estimated over specific regions where each type of aerosol is concentrated. Since the prevalent conditions represent average aerosol loading, we expect that $\tau_{\mathrm{d}}$ may be under (over) estimated on occasions of high (low) dust loading. Addition-

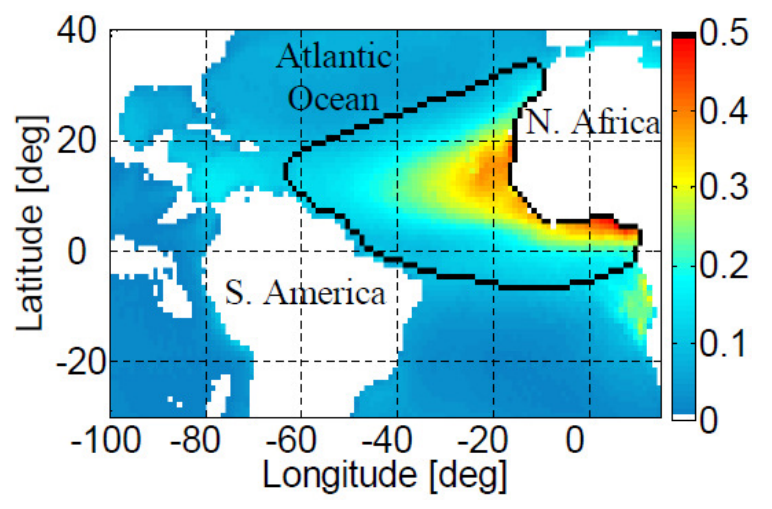

Fig. 2. Averaged values of daily $\tau_{\mathrm{d}}$ for the years 2000-2009. The study area is delineated by thick black line.

ally, $\tau_{\mathrm{d}}$ may be contaminated by the contribution of other types of aerosol. The expected error in derivation of $\tau_{\mathrm{d}}$ increases during the Sahelian biomass burning season (December to February), when the dust transport route passes over the biomass burning region and the dust is mixed with biomass smoke (e.g. Formenti et al., 2008; Weinzierl et al., 2011).

Recent field experiments and remote sensing studies proposed that the biomass smoke fine mode fraction is near unity (e.g. Johnson et al., 2008b; Capes et al., 2008; Eck et al., 2010). The value we used in this work is 0.9 , based on studies by Kaufman et al. (2005a) and Yu at al. (2009). To the best of our knowledge, there are no studies suggesting that biomass smoke fine mode fraction can be smaller than 0.9. Therefore, to estimate the sensitivity of $\tau_{\mathrm{d}}$ separation algorithm and to bound the possible error, we re-ran the calculations with biomass smoke fine mode fraction of unity (meaning, no contribution to the coarse mode by biomass smoke aerosol) and compared the results to our original results. The sensitivity analysis during the boreal winter yields an estimated bias of less than a percent and standard deviation of $\sim 18 \%$ in the $\tau_{\mathrm{d}}$ due to biomass smoke contamination. Since the distribution of the differences in $\tau_{\mathrm{d}}$ estimations is sharper than a normal distribution, our sensitivity study suggests that more than $85 \%$ of the results are bounded within an error of $\pm 18 \%$. Additional possible source of error in our analysis can be an overestimation of $\tau$ by $\sim 0.02$ due to cloudcontamination (Kaufman et al., 2005b). Nevertheless, by averaging $\tau_{\mathrm{d}}$ over large area and focusing on the low frequencies of the annual dust's cycle, we expect the above errors to be insignificant.

The study area (marked in Fig. 2) was determined based on the spatial distribution of $\tau_{\mathrm{d}}$ between the years 2000 and 2009 , as shown by the analyzed data, and in accordance with previous studies (e.g. Kaufman et al., 2005a; Huang et al., 2010). Time series of $\tau_{\mathrm{d}}$ were extracted by averaging $\tau$ measurements of both MODIS instruments over the study area. 

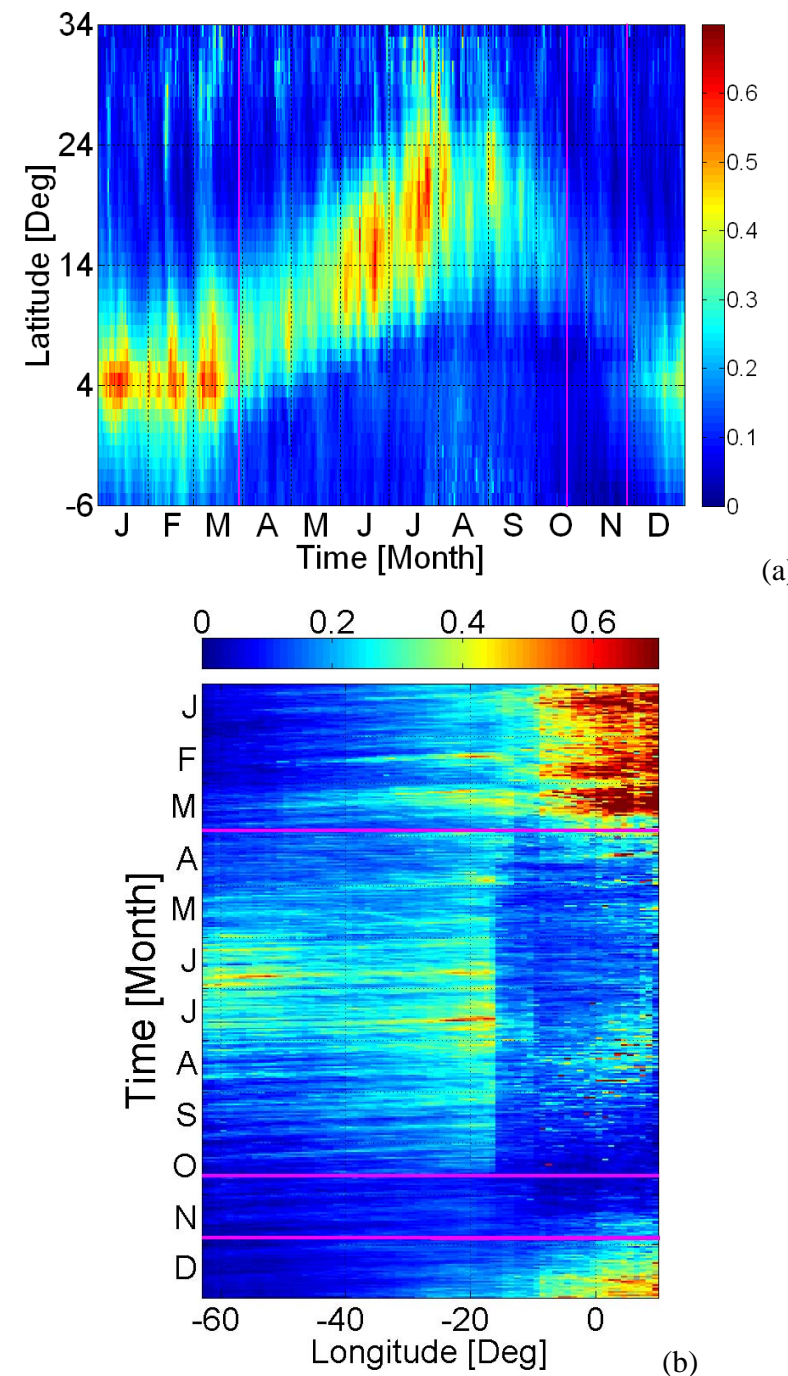

(b)

Fig. 3. Latitude-Time (a) and Longitude-Time (b) Hovmöller diagrams of $\tau_{\mathrm{d}}$ over the study area. Each diagram is based on $\sim 10 \mathrm{yr}$ of MODIS data. The y-axis in Fig. 3a marks the latitudes along the study area. The $\mathrm{x}$-axis in Fig. $3 \mathrm{~b}$ marks the longitudes along the study area. The transitions between the southern-route period, northern-route period and the clean period are marked by magenta lines.

\section{Results}

Based on analyzing the spatial distribution of dust loading $\left(\tau_{\mathrm{d}}\right)$, time series of averaged dust loading over the study area and the inter-seasonal loading frequency, we propose that the natural annual cycle of transatlantic dust follows three distinct periods and associated spatial patterns.

\subsection{Spatial distribution}

Figure 3 shows results of spatial analysis using longitudinal and latitudinal Hovmöller diagrams (Hovmöller, 1949) of $\tau_{\mathrm{d}}$ over the study area. Two distinct periods of high dust loading and one clean period, when dust loading reduces sharply, are recognized.

The first dusty period, occurring approximately between the end of November and the end of March, is characterized by southern transport route that spreads over almost unvarying latitudinal belt, centered at $\sim 4^{\circ} \mathrm{N}$. During these months, the dust is advected toward the Atlantic Ocean over the northern coast of the Gulf of Guinea and spreads between $10^{\circ} \mathrm{E}$ and $50^{\circ} \mathrm{W}$, reaching the northern part of South America. This period will hereafter be denoted as the southern-route period (SRP).

During the second dusty period, occurring approximately between the end of March and mid October, the transport route is characterized by pronounced latitudinal shift in the dust plumes location over the Atlantic of 0.1 latitude day ${ }^{-1}$ $\left(12 \mathrm{~km} \mathrm{day}^{-1}\right)$, reaching $\sim 1500 \mathrm{~km}$ northwards (Fig. 3a). Over the ocean, the dust spreads between the Saharan coast and $60^{\circ} \mathrm{W}$. The center of the dust plume, between $\sim 4^{\circ} \mathrm{N}$ and $22^{\circ} \mathrm{N}$, changes with time. This period will be called the northern-route period (NRP).

The transition from the SRP to the NRP is marked by a latitudinal shift, accompanied by a brief period of reduced $\tau_{\mathrm{d}}$. While the southern route is fixed around latitude $4^{\circ} \mathrm{N}$ (Fig. 3a), the northern route drifts northward. Between the NRP and SRP there is a clear clean period, characterized by abrupt reduction in the overall oceanic dust loading, shown as vertical and horizontal blue stripes on Fig. $3 a$ and $b$.

Focusing on oceanic regions only and averaging for all latitudes of the study area creates apparent discontinuity. During the NRP, the dust arrives the Atlantic Ocean from the Saharan coast which is located in a western position compared to the Gulf of Guinea. Therefore, during this season (NRP) relatively clean ocean is averaged over the Gulf. This creates the apparent discontinuity in the dust loading east-west gradient (Fig. 3b).

During the clean month period, the whole dust emission setting quickly migrates back south with an average speed of $\sim 0.2$ latitude day ${ }^{-1}\left(21 \mathrm{~km} \mathrm{day}^{-1}\right)$. The transport route reappears about $1300 \mathrm{~km}$ southward, near $4^{\circ} \mathrm{N}$, marking the beginning of the southern-route season and the opening of a new annual cycle (Fig. 3a).

These rates of northward advance and southward retreat in dust transport routes are in very good agreement with the rate of the ITF movement at those times of the year (Lélé and Lamb, 2010).

\subsection{Dust loading}

To compliment the information from the Hovmöller diagrams (Fig. 3), in Fig. 4a we display time series of daily $\tau_{\mathrm{d}}$ averaged over the study area along with the corresponding low-pass filter curve. The low-pass filter was tuned to the time scale of several weeks using Daubechie's wavelets (level 6, Daubechies, 1992). 


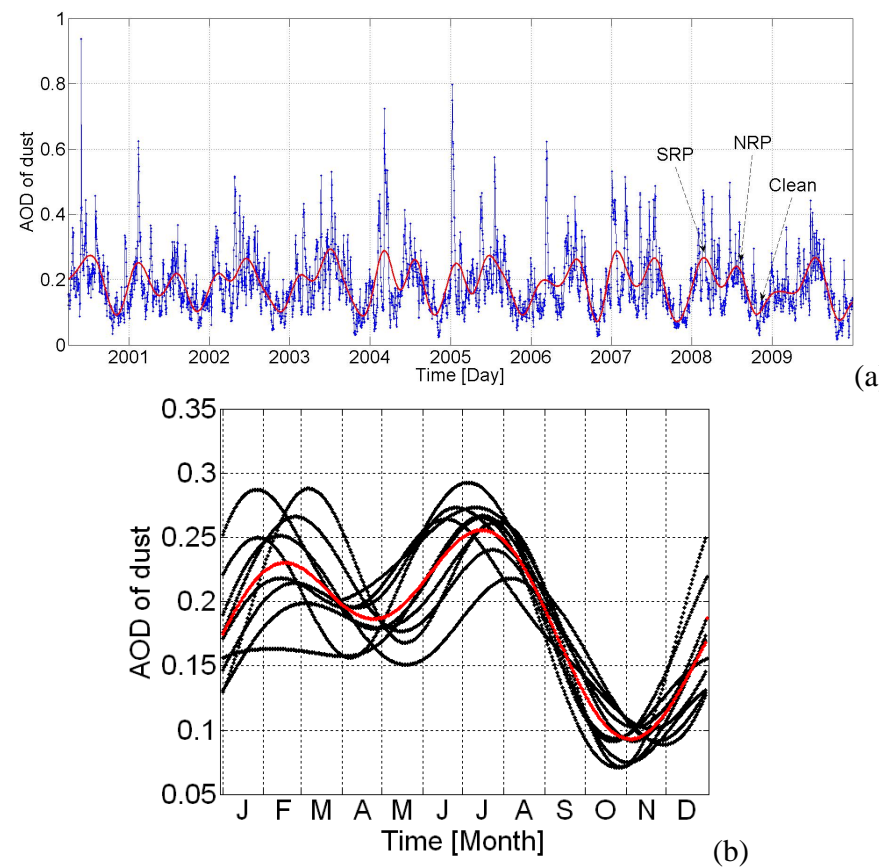

Fig. 4. (a) Daily $\tau_{\mathrm{d}}$ for the years 2000-2009, averaged over the study area (blue). Smoothed data, generated via the low-pass filter, is shown by the red curve; (b) a yearly view of all the smooth data (black) with their average marked in red. The smoothed time series clearly show a double peak feature for the SRP and NRP, followed by the clean period minimum.

The averaged filtered curve (Fig. 4a and b, red curve) shows a double peak signal followed by a clear minimum, in agreement with the classification of two dusty periods and one short clean period, as described above. The first annual maximum is attributed to the SRP and the second one to the NRP. The factor of 3 reduction in the value of $\tau_{\mathrm{d}}$, from average of $\sim 0.24$, during the maxima of the NRP, to $\sim 0.08$, during the minima of the clean period, renders this a distinct period: the atmosphere over this part of the Atlantic Ocean is substantially less dusty and more transparent.

Extreme episodes are evident during both dusty periods (Fig. 4a, blue curve - not filtered data). These events appear as distinct peaks that are up to 5 times higher than the local average (Fig. 4a, red curve). The existence of such spikes, despite the spatial averaging over area of more than $15 \times 10^{6} \mathrm{~km}^{2}$, suggests a coherent emission of dust from many sources throughout North Africa. These massive emissions occur only a few times per year. The unusual weather conditions during these events and part of their climatic impacts were described by Knippertz and Fink (2006), Slingo et al. (2006), Cavazos et al. (2009), Tulet et al. (2008), Thomas and Gautier (2009), and Bou Karam et al. (2010).

Following up on the periodicity gleaned from the time series of $\tau_{\mathrm{d}}$, as shown in Fig. $4 \mathrm{a}$ and $\mathrm{b}$, and plotting the daily averaged $\tau_{\mathrm{d}}$ vs. the day in the year, major differences be- a.

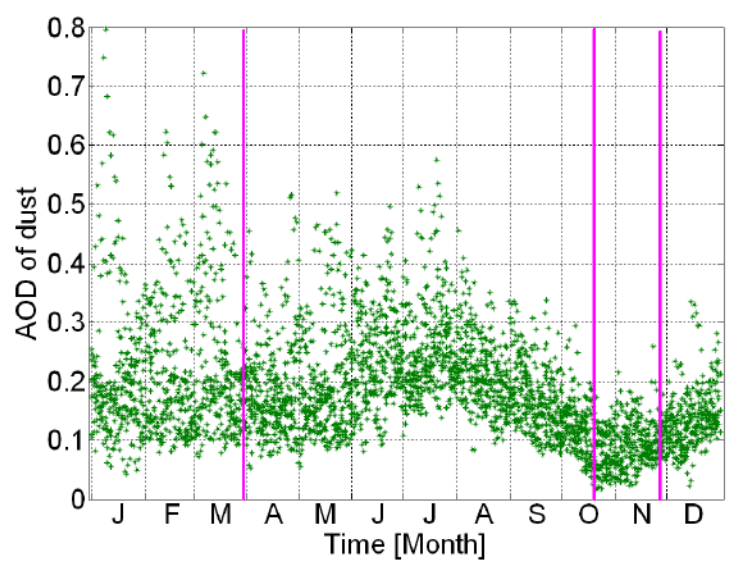

b.

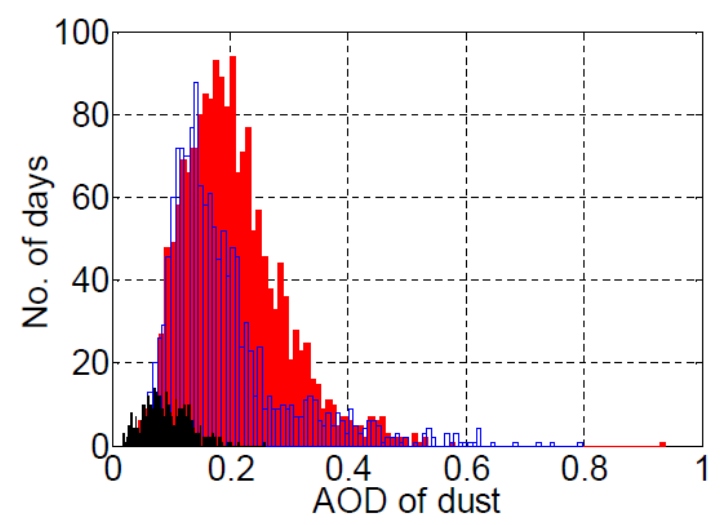

Fig. 5. (a) Daily $\tau_{\mathrm{d}}$ averaged over the study area for the years $2000-$ 2009 plotted as a function of time. The transitions between the SRP the NRP and the clean period are marked by magenta lines; (b) histograms of daily $\tau_{\mathrm{d}}$ for the years 2000-2009, averaged over the study area for the NRP (red), SRP (blue) and the clean period (black).

tween the SRP and the NRP are revealed (Fig. 5a). It is apparent that the SRP is characterized by an almost constant background dust loading of $\tau_{\mathrm{d}} \sim 0.15$. On top of this flat background there are events of very high dust loading with daily average $\tau_{\mathrm{d}}>0.5$, represented also by the pronounced right tail in the corresponding histogram of $\tau_{\mathrm{d}}$ as shown in Fig. 5b. High variance in dust loading during this period is in agreement with previous studies (e.g. Chiapello and Moulin, 2002). In contrast, the NRP background dust loading changes through time: it increases from approximately 0.15 at the beginning of the period to 0.25 at the peak of the period (mid July), followed by a decrease to values of less than 0.1 during the minimum of the clean period (early November). The variance of $\tau_{\mathrm{d}}$ during the NRP (0.007) drop by more than an order of magnitude relative to that of the SRP (0.01), suggesting a more continuous flow of dust to the ocean during the NRP. 
a.

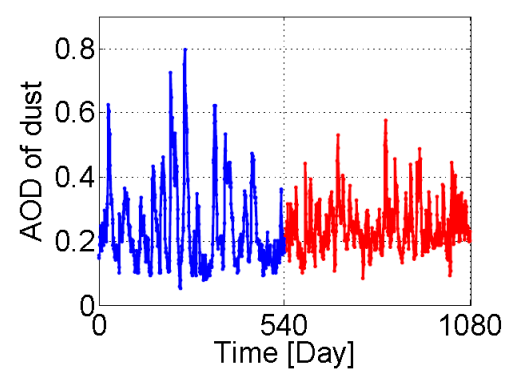

b.

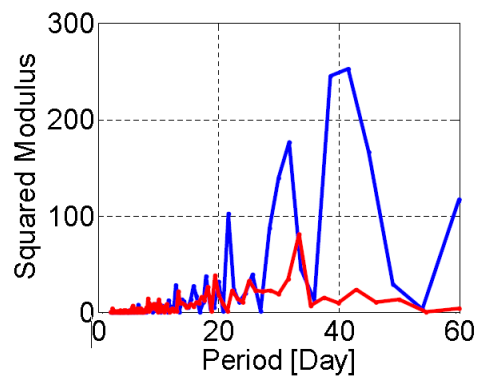

c.

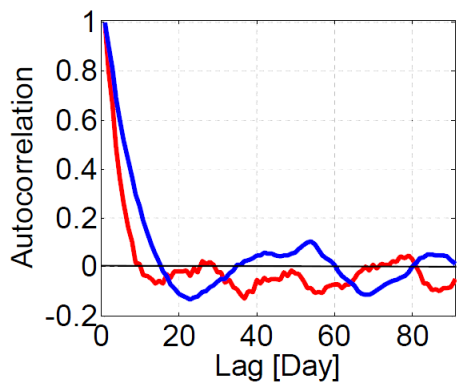

Fig. 6. (a) Time series of the SRP (blue) and the NRP (red) signal after subtraction of the seasonality curve. Each signal is composed of 9 segments from $9 \mathrm{yr}$ and each segment contains 60 days around the maxima of the period (see red line in Fig. $4 \mathrm{a}$ ), total of 540 points; (b) results of Fourier transform of the two signals in Fig. 6a; (c) autocorrelation function for the two periods.

\subsection{Inter-seasonal frequency content}

Following the above results we explored the spectral content of the two dusty seasons in more detail. For each period, segments of 60 days around each maximum (see Fig. 4a, red curve) were concatenated into a single continuous time series throughout the $9 \mathrm{yr}$ between 2001 and 2009, keeping the chronological order. The seasonal trends were removed by subtracting the low frequency curve, representing the average annual trend, from the daily data (i.e. blue curve minus the red curve, Fig. 4a).

Figure 6a shows the two time series generated for the SRP and the NRP. The frequency content, in means of periods of both signals, is shown in Fig. 6b. The differences in the patterns of dust loading are clearly evident both in the time series and in the frequency domain. The SRP has pronounced intense and longer-lasting coherent events. This can also be seen from the autocorrelation curves (Fig. 6c): SRP decays more slowly than the NRP and exhibits higher correlations for longer lags.

\subsection{What is the role of the Bodélé depression in the an- nual cycle of transatlantic dust?}

Is there possibly a causal connection between dust emissions from the Bodélé and dust loading over the Atlantic? To that end, we calculated the cross-correlation between the dust loading over the Bodélé (using the deep blue algorithm, Hsu et al., 2004) with the Atlantic one. Indeed, Fig. 7a reveals a coherent correlation signal driven by the annual cycle and a clear spike of much higher correlation on a $\sim 3-5$ days lag. This is in complete agreement with the average time it takes the dust to travel from the Bodélé, over the western coast of Africa, and as far as the middle of the Atlantic Ocean (BenAmi et al., 2010). Figure $7 \mathrm{~b}$ and $\mathrm{c}$ is for the same signals but with the low-pass seasonal cycle removed.

To further investigate which part of the year contributes to the observed correlation, we did the following analysis: a subset of 3 months was extracted from the AOD of dust time a.

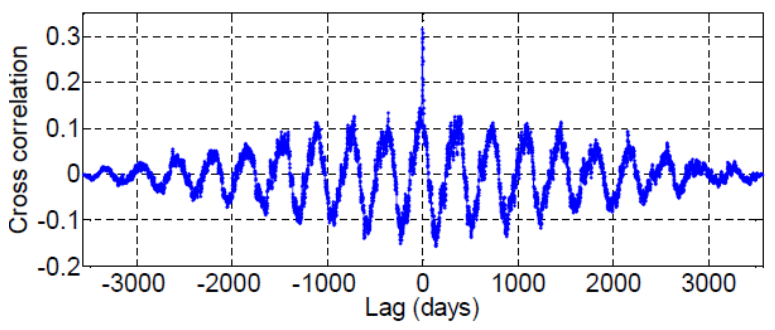

b.

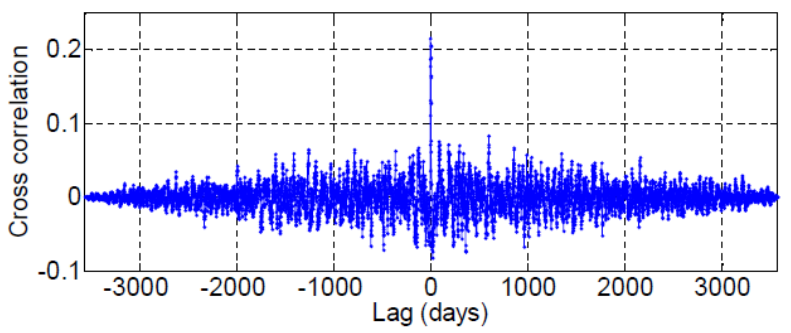

c.

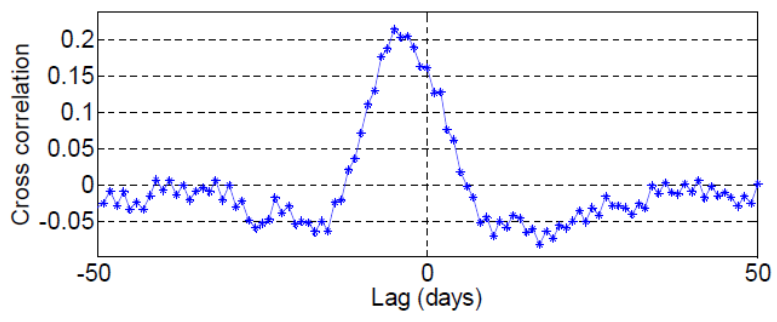

Fig. 7. Cross-correlation between the Bodélé AOD loading (for the area between $18-15^{\circ} \mathrm{N}$ and $15-19^{\circ} \mathrm{E}$ ) and $\tau_{\mathrm{d}}$ over the Atlantic Ocean (area marked in Fig. 2) before (a), and after (b) subtracting the seasonal signal; (c) enlargement of Fig. $7 \mathrm{~b}$ for 50 days lag.

series of each of the $10 \mathrm{yr}$. The same duration was extracted for both the Bodélé and the Atlantic data for which a correlation was calculated for a range of time lags. The maximum correlation and the relevant time lag were kept. Next, the same analysis was repeated shifting the 3 month sampling range by one day. Such analysis (defined here as running 


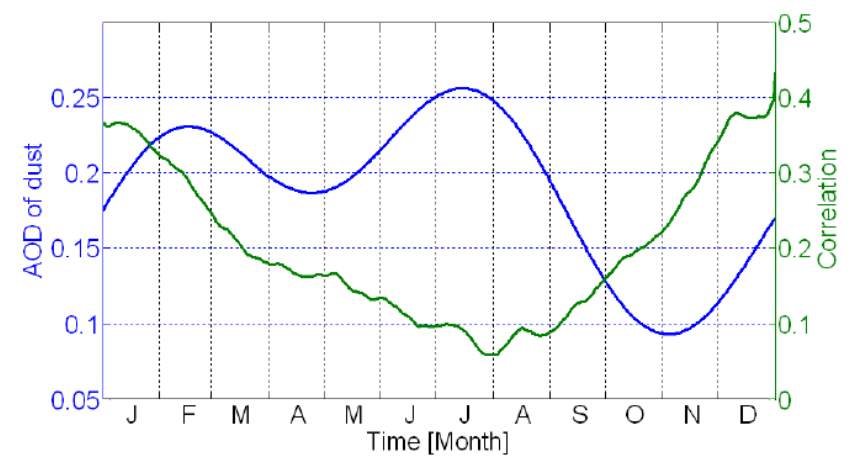

Fig. 8. Three months running correlation analysis between the Bodélé dust loading and the Atlantic AOD signal (green). The corresponding low pass dust loading over the Atlantic is shown in blue.

correlation) identifies the parts of the year that contribute the most to the significant synchronicity with the 3 to 5 days lags demonstrated above.

Figure 8 shows that the correlation function maximizes to a value of more than 0.3 and 0.4 during the SRP and minimizes to values of less than 0.1 during the peak of the NRP, when the dust sources location and transport route migrates northwards. The time lag for running correlation analysis is between 3 and 5 days for the SRP and 6 to 8 days for the NRP but with much larger variance.

\section{Discussion}

We showed that dust transport over the Atlantic has an annual triple rhythm composed of two dusty periods followed by a short but distinct clean period. The two dust periods last about 4 and 6.5 months and are different not only in their route location but also in the patterns by which dust is transported over the ocean.

The Southern-route period (SRP) starts around the end of November and ends around the end of March. It is characterized by low levels of background and high variance in dust loading, with coherent and strong events of dust emission that modify the oceanic dust loading for periods as long as two weeks. The transport route is almost stationary around latitude $4^{\circ} \mathrm{N}$, all along the period.

The northern-route period (NRP) is different in all aspects. It starts around end of March and ends around mid October, when Atlantic dust approaches to a minimum loading of less than 0.1 rather fast. Unlike during the SRP, changes in the oceanic dust loading are less episodic. There is a gradual increase in the background dust loading values, reaching its peak around mid July. In contrast to the stationary route pattern of the SRP, the NRP is characterized by a steady migration northward of more than $1500 \mathrm{~km}$ in the dust route, between the beginning of the period and its peak. The NRP ends with a short southward movement of the route from latitude $22^{\circ} \mathrm{N}$, during the peak of the season, to $\sim 14^{\circ} \mathrm{N}$ near its end.

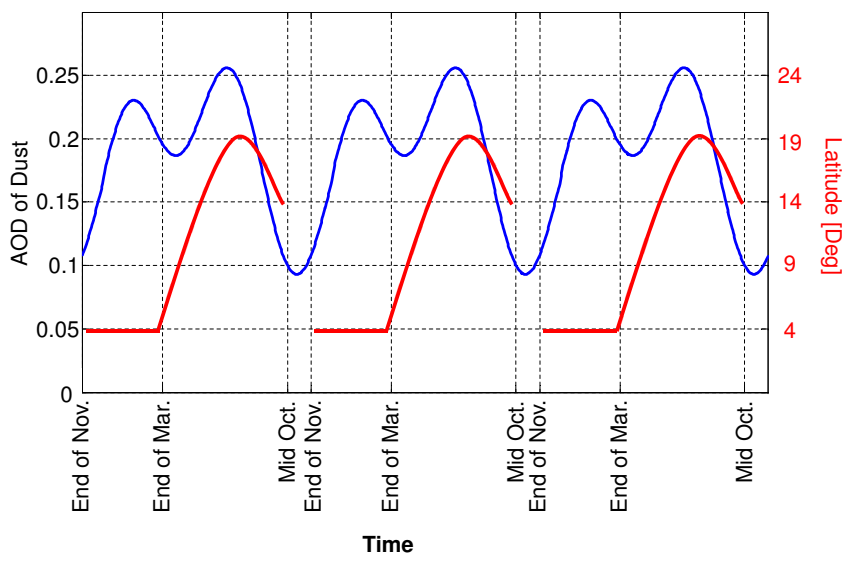

Fig. 9. Schematic illustration of the tri-beat rhythm of the dust loading (in blue) and routes (in red) over the Atlantic.

During the clean period the average dust loading reduces abruptly to levels of less than $0.1,2$ to 3 times less than the typical loading during the dusty periods. At that time, the whole system continues, rests to the southern route of around latitude $4^{\circ} \mathrm{N}$. This period lasts about 5-6 weeks. Figure 9 illustrates schematically the triple beat of the dust loading and the chain saw pattern of dust transport routes over the ocean, the "transatlantic dust weather".

To what extent is this triple beat rhythm linked to the rhythm of emission of the dust sources? Roughly, dust emission can be regarded as a convolution of the source properties and meteorological conditions: source properties such as mineral content, particle size distribution, vegetation cover, topography and location will determine the potential for available dust. Meteorology governs the triggering of a given source by determining the key environmental factors for dust emission, such as surface winds, humidity and transport winds. The combination between the above factors will determine how likely this is to be translated into suspended dust flux in the atmosphere.

As a rough approximation, the location of the ITCZ can be a good indicator of the dust meteorology. As stated in the introduction, the synoptic systems that are related to dust emission over North Africa are all moving with the ITCZ and the ITF. Unlike the NRP that closely follows these systems, the SRP stays stationary over latitude $4^{\circ} \mathrm{N}$. This can be viewed as a result of the dust sources spatial distribution and their properties.

North of the Sahel, all along the western part of the Sahara, there are clusters of many dust sources (Formenti et al., 2011, and the reference therein). Some of these are quite localized but distributed throughout the Western Sahara. The location of the southern sources is bounded by the Sahel that marks the transition from the desert to the savannah. Unlike the northwestern Sahara dust sources, the source distribution on the southern border of the Sahara is sparser, dominated by the world's vigorous dust source, the Bodélé depression. In 
addition, while the sources in north and west Africa (e.g. in Mali, Mauritania, southern Algeria and Western Sahara) are located near the west coast or up to $\sim 1800 \mathrm{~km}$ from the ocean, the Bodélé depression is located about $1800 \mathrm{~km}$ from the Gulf of Guinea and between 3000 and $3700 \mathrm{~km}$ from the western Saharan coast. This contrast, between the northern and the southern source distributions, can explain many of the presented phenomena of this paper: many smaller dust sources distribute along the western part of the Sahara, and closer to the ocean will emit dust plumes that will follow the location of the maximum surface winds that moves with the ITCZ and the ITF northwards. In contrast, lack of dust sources south of the Sahel will limit transport route to the south. However, the Bodélé depression does supply high dust loading when the surface wind over it exceeds the threshold wind (Koren and Kaufman, 2004). Therefore, during the NRP we expect high background dust levels, dominated by high frequencies events, marking the contribution of numerous small sources that are closer to the ocean; and during the SRP we expect lower frequencies that characterize a single and far, but large source dust emission patterns (the Bodélé).

The cross correlation analysis showed clear synchrony between the Bodélé AOD time series and the Atlantic one. The clear spike in correlation in $\sim 3$ to 5 days lag suggests that the Bodélé is a key source. The detailed running correlation analysis showed that during the SRP the correlations peaked to values of more than 0.4 . Such correlation is surprisingly high, given the fact that the area around the Bodélé, where AOD data were collected $\left(\sim 140000 \mathrm{~km}^{2}\right)$, occupies less than one percent of the Atlantic area in which the AOD of dust is averaged for (more than $15 \times 10^{6} \mathrm{~km}^{2}$ ).

This correlation analysis is additional evidence for the preponderance of dust in winter plumes. The high correlation between a specific source (e.g. Bodélé) and the plumes arriving at the middle of the ocean should be obscured by a spatially random biomass smoke contamination, if the fraction of the latter is significant. This is particularly noteworthy for the 3-5 days time lag of the cross-correlation, which so nicely fits the duration of transatlantic transit. Thus, insofar as our main results rely on the cross-correlation analysis, the biomass smoke contamination of the dust signal is somewhat circumvented and constrained by the temporal signature.

The above results suggest that for the SRP, the Bodélé being the dominant source, serves as a metronome for the Atlantic dust transport, lagging the Bodélé emissions by 3 to 5 days, whereas during the NRP the small but dense northwestern Saharan sources dominate. Similar analysis for northwestern Saharan source area shows no significant spikes for the cross correlations and the running correlation analysis peaked to a value of $\sim 0.2$ during the NRP.
Acknowledgements. This research was supported, in part, by the Israel Science Foundation (grant No. 1172 \10), and by the Minerva Foundation (grant 780048). Alex B. Kostinski was supported, in part, by NSF AGS-1119164.

Edited by: J. Quaas

\section{References}

Ansmann, A., Petzold, A., Kandler, K., Tegen, I., Wendisch, M., D Muller, Weinzierl B., Muller, T., and Heintzenberg, J.: Saharan Mineral Dust Experiments SAMUM-1 and SAMUM-2: what have we learned?, Tellus, 63B, 403-429, doi:10.1111/j.16000889.2011.00555.x, 2011.

Ben-Ami, Y., Koren, I., and Altaratz, O.: Patterns of North African dust transport over the Atlantic: winter vs. summer, based on CALIPSO first year data, Atmos. Chem. Phys., 9, 7867-7875, doi:10.5194/acp-9-7867-2009, 2009.

Ben-Ami, Y., Koren, I., Rudich, Y., Artaxo, P., Martin, S. T., and Andreae, M. O.: Transport of North African dust from the Bodélé depression to the Amazon Basin: a case study, Atmos. Chem. Phys., 10, 7533-7544, doi:10.5194/acp-10-7533-2010, 2010.

Bou Karam, D., Flamant, C., Cuesta, J., Pelon, J., and Williams, E.: Dust emission and transport associated with a Saharan depression: The February 2007 case, J. Geophys. Res., 115, D00H27, doi:10.1029/2009JD012390, 2010.

Capes, G., Johnson, B., McFiggans, G., Williams, P. I., Haywood J., and Coe, H.: Aging of biomass burning aerosols over West Africa: Aircraft measurements of chemical composition, microphysical properties, and emission ratios, J. Geophys. Res.Atmos., 113, D00C15, doi:10.1029/2008JD009845, 2008.

Cavazos, C., Todd, M. C., and Schepanski, K.: Numerical model simulation of the Saharan dust event of 6-11 March 2006 using the Regional Climate Model version 3 (RegCM3), J. Geophys. Res. Atmos., 114, D12109, doi:10.1029/2008JD011078, 2009.

Chiapello, I. and Moulin, C.: TOMS and METEOSAT satellite records of the variability of Saharan dust transport over the Atlantic during the last two decades (1979-1997), J. Geophys. Res. Lett., 29, 17-20, doi:10.1029/2001GL013767, 2002.

Christopher, A. D. and Jones, T. A.: Satellite and surface-based remote sensing of Saharan dust aerosols, Remote Sens. Environ., 114, 1002-1007, 2010.

Daubechies, I.: Ten lectures on wavelets, CBMS-NSF Lecture Notes nr. 61, SIAM, Philadelphia, 1992.

Eck, T. F., Holben, B. N., Sinyuk, A., Pinker, R. T., Goloub, P., Chen, H., Chatenet, B., Li, Z., Singh, R. P., Tripathi, S. N., Reid, J. S., Giles, D. M., Dubovik, O., O’Neill, N. T. Smirnov, A. Wang, P., and Xia, X.: Climatological aspects of the optical properties of fine/coarse mode aerosol mixtures, J. Geophys. Res., 115, D19205, doi:10.1029/2010JD014002, 2010.

Engelstaedter, S. and Washington, R.: Atmospheric controls on the annual cycle of North African dust, J. Geophys. Res., 112, D03103, doi:10.1029/2006jd007195, 2007.

Engelstaedter, S., Washington, R., and Mahowald, N.: Impact of changes in atmospheric conditions in modulating summer dust concentration at Barbados: A back-trajectory analysis, J. Geophys. Res., 114, D17111, doi:10.1029/2008JD011180, 2009. 
Formenti, P., Rajot, J. L., Desboeufs, K., Caquineau, S., Chevaillier, S., Nava, S., Gaudichet, A., Journet, E., Triquet, S., Alfaro, S., Chiari, M., Haywood, J., Coe, H., and Highwood, E.: Regional variability of the composition of mineral dust from western Africa: Results from the AMMA SOP0/DABEX and DODO field campaigns, J. Geophys. Res., 113, D00C13, doi:10.1029/2008JD009903, 2008.

Formenti, P., Schütz, L., Balkanski, Y., Desboeufs, K., Ebert, M., Kandler, K., Petzold, A., Scheuvens, D., Weinbruch, S., and Zhang, D.: Recent progress in understanding physical and chemical properties of African and Asian mineral dust, Atmos. Chem. Phys., 11, 8231-8256, doi:10.5194/acp-11-8231-2011, 2011.

Ginoux, P., Prospero, J. M., Torres, O., and Chin, M.: Long-term simulation of global dust distribution with the GOCART model: correlation with North Atlantic Oscillation, Environ. Modell. Softw., 19, 113-128, doi:10.1016/S1364-8152(03)00114-2, 2004.

Haywood, J., Francis, P., Osborne, S., Glew, M., Loeb, N., Highwood, E., Tanré, D., Myhre, G., Formenti, P., and Hirst, E.: Radiative properties and direct radiative effect of Saharan dust measured by the C-130 aircraft during SHADE: 1. Solar spectrum, J. Geophys. Res., 108, 8577, doi:10.1029/2002JD002687, 2003.

Hovmöller, E.: The trough and ridge diagram, Tellus, 1, 62-66, 1949.

Hsu, N. C., Tsay, S. C., King, M. D., and Herman, J. R.: Aerosol properties over bright-reflecting source regions, IEEE T. Geosci. Remote Sens., 42, 557-569, 2004.

Huang, J., Zhang, C., and Prospero, J. M.: African dust outbreaks: A satellite perspective of temporal and spatial variability over the tropical Atlantic Ocean, J. Geophys. Res., 115, D05202, doi:10.1029/2009JD012516, 2010.

Huneeus, N., Schulz, M., Balkanski, Y., Griesfeller, J., Prospero, J., Kinne, S., Bauer, S., Boucher, O., Chin, M., Dentener, F., Diehl, T., Easter, R., Fillmore, D., Ghan, S., Ginoux, P., Grini, A., Horowitz, L., Koch, D., Krol, M. C., Landing, W., Liu, X., Mahowald, N., Miller, R., Morcrette, J.-J., Myhre, G., Penner, J., Perlwitz, J., Stier, P., Takemura, T., and Zender, C. S.: Global dust model intercomparison in AeroCom phase I, Atmos. Chem. Phys., 11, 7781-7816, doi:10.5194/acp-11-7781-2011, 2011.

Janicot, S., Thorncroft, C. D., Ali, A., Asencio, N., Berry, G., Bock, O., Bourles, B., Caniaux, G., Chauvin, F., Deme, A., Kergoat, L., Lafore, J.-P., Lavaysse, C., Lebel, T., Marticorena, B., Mounier, F., Nedelec, P., Redelsperger, J.-L., Ravegnani, F., Reeves, C. E., Roca, R., de Rosnay, P., Schlager, H., Sultan, B., Tomasini, M., Ulanovsky, A., and ACMAD forecasters team: Large-scale overview of the summer monsoon over West Africa during the AMMA field experiment in 2006, Ann. Geophys., 26, 2569 2595, doi:10.5194/angeo-26-2569-2008, 2008.

Jickells, T. D., An, Z. S., Andersen, K. K., Baker, A. R., Bergametti, G., Brooks, N., Cao, J. J., Boyd, P. W., Duce, R. A., Hunter, K. A, Kawahata, H., Kubilay, N., la Roche, J., Liss, P. S., Mahowald, N., Prospero, J. M., Ridgwell, A. J., Tegen, I., and Torres, R.: Global Iron Connections Between Desert Dust, Ocean Biogeochemistry and Climate, Science, 308, 67-71, doi:10.1126/science.1105959, 2005

Johnson, B. T., Heese, B., McFarlane, S. A., Chazette, P., Jones, A., and Bellouin, N.: Vertical distribution and radiative effects of mineral dust and biomass burning aerosol over west Africa during DABEX, J. Geophys. Res., 113, D00C12,
doi:10.1029/2008JD009848, 2008a.

Johnson, B. T., Osborne, S. R., Haywood, J. M., and Harrison, M. A. J.: Aircraft measurements of biomass burning aerosol over West Africa during DABEX, J. Geophys. Res., 113, D00C06, doi:10.1029/2007JD009451, 2008b.

Kalnay, E., Kanamitsu, M., Kistler, R., Collins, W., Deaven, D., Gandin, L., Iredell, M., Saha, S., White, G.,Woollen, J., Zhu, Y., Leetmaa, A., Reynolds, R., Chelliah, M., Ebisuzaki,W., Higgins, W., Janowiak, J., Mo, K. C., Ropelewski, C., Wang, J., Jenne, R., and Joseph, D.: The NCEP/NCAR 40-Year Reanalysis Project, B. Am. Meteorol. Soc., 3, 437-471, 1996.

Kalu, A. E.: The African dust plume: Its characteristics and propagation across west Africa in winter, SCOPE, 14, 95-118, 1979.

Karyampudi, V. M. and Carlson, N. T.: Analysis and numerical simulations of the Saharan Air Layer and its effect on easterly wave disturbances, J. Atmos. Sci., 45, 3102-3136, 1988.

Karyampudi, V. M., Palm, S. P., Reagen, J. A., Fang, H., Grant, W. B., Hoff, R. M., Moulin, C., Pierce, H. F., Torres, O., Browell, E. V., and Melfi, S. H.: Validation of the Saharan dust plume conceptual model using lidar, Meteosat and ECMWF, B. Am. Meteorol. Soc., 80, 1045-1075, 1999.

Kaufman, Y. J., Koren, I., Remer, L. A., Tanre, D., Ginoux, P., and Fan, S.: Dust transport and deposition observed from the Terra-Moderate Resolution Imaging Spectroradiometer (MODIS) spacecraft over the Atlantic Ocean, J. Geophys. Res., 110, D10S12, doi:10.1029/2003JD004436, 2005a.

Kaufman, Y. J., Remer, L. A., Tanre, D., Li, R. R., Kleidman, R., Mattoo, S., Levy, R., Eck, T., Holben, B. N., Ichoku, C., Martins, J., and Koren, I.: A critical examination of the residual cloud contamination and diurnal sampling effects on MODIS estimates of aerosol over ocean, IEEE T. Geosci. Remote Sens., 43, 2886 2897, 2005b

Knippertz, P. and Fink, A. H.: Synoptic and Dynamic Aspects of an Extreme Springtime Saharan Dust Outbreak, J. Roy. Meteorol. Soc., 132, 1153-1177, doi:10.1256/qj.05.109, 2006.

Knippertz, P., Tesche, M., Heinold, B., Kandler, K., Toledano, C., and Esselborn, M.: Dust mobilization and aerosol transport from West Africa to Cape Verde: a meteorological overview of SAMUM-2, Tellus, 63B, 430-447, doi:10.1111/j.16000889.2011.00544.x, 2011.

Koren, I. and Kaufman, Y. J.: Direct wind measurements of Saharan dust events from Terra and Aqua satellites, J. Geophys. Res. Lett., 31, L06122, doi:10.1029/2006GL026024, 2004.

Koren, I., Kaufman, Y. J., Washington, R., Todd, C. C., Rudich, Y., Martins, J. V., and Rosenfeld, D.: The Bodélé depression: a single spot in the Sahara that provides most of the mineral dust to the Amazon forest, Environ. Res. Lett., 1, 1-5, 2006.

Lavaysse, C., Flamant, C., Janicot, S., Parker, D. J., Lafore, J. P., Sultan, B., and Pelon, J.: Seasonal evolution of the West African heat low: A climatological perspective, Clim. Dynam., 33, 313 330, doi:10.1007/s00382-009-0553-4, 2009.

Lélé, M. I. and Lamb, P. J.: Variability of the Intertropical Front (ITF) and rainfall over the West African Sudan-Sahel zone, J. Climate, 23, 3984-4004, doi:2010/10.1175JCLI3277.1, 2010.

Ozer, P., Laghdaf, M., Lemine, S. O. M., and Gassani, J.: Estimation of air quality degradation due to Saharan dust at Nouakchott, Mauritania, from horizontal visibility data, Water Air Soil Poll., 178, 79-87, 2007.

Prenni, A. J., Petters, M. D., Kreidenweis, S. M., Heald, C. L., 
Martin, S. T., Artaxo, P., Garland, R. M., Wollny, A. G., and Pöschl, U.: Relative roles of biogenic emissions and Saharan dust as ice nuclei in the Amazon Basin, Nat. Geosci., 2, 402405, 2009.

Prospero, J. M.: The atmospheric transport of particles to the ocean, in: Particle Flux in the Ocean, SCOPE Report 57, edited by: Ittekkot, V., Schäfer, P., Honjo, S., and Depetris, P. J., John Wiley \& Sons Chichester, 19-52, 1996.

Prospero, J. M.: Long-term measurements of the transport of African mineral dust to the southeastern United States: Implications for regional air quality, J. Geophys. Res., 104, 1591715927, 1999.

Prospero, J. M. and Carlson, T. N.: Vertical and areal distribution of Saharan dust over the western equatorial North Atlantic ocean, J. Geophys. Res., 77, 5255-5265, 1972.

Prospero, J. M. and Nees, R. T.: Dust concentration in the atmosphere of the equatorial North Atlantic: Possible relationship to the Sahelian drought, Science, 196, 1196-1198, 1977.

Reid, J. S., Westphal, D., Livingston, J. M., Savoie, D. L., Maring, H. B., Jonsson, H. H., Eleuterio, D. P., Kinney, J. E., and Reid, E. A.: Dust vertical distribution in the Caribbean during the Puerto Rico Dust Experiment, J. Geophys. Res., 29, 1151, doi:10.1029/2001GL014092, 2002.

Reid, J. S., Kinney, J. E., Westphal, D. L., Holben, B. N., Welton, E. J., Tsay, S., Eleuterio, D. P., Campbell, J. R., Christopher, S. A., Colarco, P. R., Jonsson, H. H., Livingston, J. M., Maring, H. B., Meier, M. L., Pilewskie, P., Prospero, J. M., Reid, E. A., Remer, L. A., Russell, P. B., Savoie, D. L., Smirnov, A., and Tanré, D.: Analysis of measurements of Saharan dust by airborne and ground-based remote sensing methods during the Puerto Rico Dust Experiment (PRIDE), J. Geophys. Res., 108, D19, 8586, doi:10.1029/2002JD002493, 2003.

Remer, L. A., Kleidman, R. G., Levy, R. C., Kaufman, Y. J., Tanre, D., Mattoo, S., Martins, J. V., Ichoku, C., Koren, I., Yu, H. B., and Holben, B. N.: Global aerosol climatology from the MODIS satellite sensors, J. Geophys. Res., 113, D14S07, doi:10.1029/2007JD009661, 2008.

Schepanski, K., Tegen, I., and Macke, A.: Saharan dust transport and deposition towards the tropical northern Atlantic, Atmos. Chem. Phys., 9, 1173-1189, doi:10.5194/acp-9-1173-2009, 2009.
Slingo, A., Ackerman, T. P., Allan, R. P., Kassianov, E. I., McFarlane, S. A., Robinson, G. J., Barnard, J. C., Miller, M. A., Harries, J. E., Russell, J. E., and Dewitte, S.: Observations of the impact of a major Saharan dust storm on the atmospheric radiation balance, J. Geophys. Res., 33, L24817, doi:10.1029/2006GL027869, 2006.

Thomas, M. and Gautier, C.: Investigations of the March 2006 African dust storm using ground-based column-integrated high spectral resolution infrared $(8-13 \mu \mathrm{m})$ and visible aerosol optical thickness measurements: 2 Mineral aerosol mixture analyses, J. Geophys. Res., 114, D14209, doi:10.1029/2008JD010931, 2009.

Torres, O., Bhartia, P. K., Herman, J. R., Sinyuk, A., Ginoux, P., and Holben, B.: A long-term record of aerosol optical depth from TOMS observations and comparison to AERONET measurements, J. Atmos. Sci., 59, 398-413, 2002.

Tulet, P., Mallet, M., Pont, V., Pelon, J., and Boone, A.: The 713 March 2006 dust storm over West Africa: Generation, transport, and vertical stratification, J. Geophys. Res., 113, D00C08, doi:10.1029/2008JD009871, 2008.

Usher, C. R., Michel, A. E., and Grassian, V. H.: Reactions on mineral dust, Chem. Rev., 103, 4883-4939, 2003.

Washington, R. and Todd, M. C.: Atmospheric controls on mineral dust emission from the Bodélé Depression, Chad: The role of the low level jet, J. Geophys. Res., 32, L17701, doi:10.1029/2005GL023597, 2005.

Weinzierl, B., Sauer, D., Esselborn, M., Petzold, A., Veira, A., Rose, M., Mund, S., Wirth, M., Ansmann, A., Tesche, M., Gross, S., and Freudenthaler, V.: Microphysical and optical properties of dust and tropical biomass burning aerosol layers in the Cape Verde region - an overview of the airborne in situ and lidar measurements during SAMUM-2, Tellus, 63B, 589-618, doi:10.1111/j.1600-0889.2011.00566.x, 2011.

Yu, H. B., Chin, M., Remer, L. A., Kleidman, R. G., Bellouin, N., Bian, H. S., and Diehl, T.: Variability of marine aerosol fine mode fraction and estimates of anthropogenic aerosol component over cloud-free oceans from the Moderate Resolution Imaging Spectroradiometer (MODIS), J. Geophys. Res.-Atmos., 114, D10206, doi:10.1029/2008JD010648, 2009. 